\title{
“PARA LER É PRECISO SABER ASSOCIAR": UMA TEORIA DA LEITURA EM RESPIRAÇÃO ARTIFICIAL
}

\section{"TO READ IS NECESSARY TO KNOW TO CONNECT": A THEORY OF READING IN RESPIRAÇÃO ARTIFICIAL}

Ieda Magri ${ }^{1}$

Universidade Estadual do Rio de Janeiro, UERJ, Rio de Janeiro, RJ, Brasil

\begin{abstract}
Resumo: O texto busca sentidos variáveis para a irrupção do relato de Tardewski a Emílio Renzi na noite que passam em claro em Concórdia à espera de Marcelo Maggi em Respiração artificial (1987), romance de Ricardo Piglia. Um relato que se diferencia dos demais por colocar em cena uma mulher que "escreve belamente", mas que acredita não poder ser escritora, uma mulher que afirma só ser possível escrever com o próprio corpo. Usando procedimentos de Piglia defendidos no romance e em outros textos, especula-se sobre uma teoria da leitura como reversibilidade da escrita que estaria cifrada no relato e defendida enquanto associação.
\end{abstract}

Palavras-chave: escrita; leitura; autobiografia; segredo; enigma

Abstract: this text seeks variable meanings for the outbreak of Tardewski's account to Emílio Renzi the night they spend in Concordia waiting for Marcelo Maggi in Respiraçâo artificial (1987), Ricardo Piglias novel. A story that differs from the others in that it features a woman who "writes beautifully" but who believes she cannot be a writer, a woman who claims that it is only possible to write with her own body. Using Piglia's procedures defended in the novel and other texts, it is speculated on a theory of reading as a reversibility of writing that would be ciphered in the report and defended as an association.

Keywords: writing; reading; autobiography; secret; enigma

Más bien esos libros — o quizás la literatura misma tienen siempre algo que no se entiende, que no se alcanza a decifrar y que nos perturba. ${ }^{2}$

(PIGLIA, 2015, p. 179)

\footnotetext{
${ }^{1} \mathrm{O}$ presente artigo faz parte do projeto de pesquisa "Literatura brasileira e latino-americana: questóes de inserção no cenário contemporâneo", apoiado pela FAPERJ no Programa Jovem Cientista do Nosso Estado (JCNE).

${ }^{2}$ Tradução nossa: "Em vez disso, esses livros - ou talvez a própria literatura - sempre têm algo que não é compreendido, que não pode ser decifrado e que nos perturba”.
} 
Ao reler Respiraçáo artificial (1987), numa espécie de homenagem ao escritor argentino Ricardo Piglia quando de sua morte no início de 2017, me senti impelida a parar naquilo que passei a chamar de "enigma de Sua" em busca de um outro modo de ler o romance: um modo de ler que partisse dessa estranha personagem que escreve muito bem, mas que não acredita fazê-lo por causa do que sente em relação ao próprio corpo como empecilho da escrita. Naquela longa noite que Renzi passa com Tardewski, depois de sair do clube em Concórdia onde defende Arlt como o mais importante escritor argentino do século XX, deixando Borges no $\mathrm{IX}^{3}$, aparece na conversação a alusão a essa personagem da mulher feia que envia cartas belíssimas a Marconi, "o personagem local do Poeta" (PIGLIA, 1987, p. 144), e assina "Sua", além do nome e do endereço, o que Marconi prefere omitir ao contar o relato a Tardewski, uns dias antes, no mesmo clube. Quem narra a Renzi é Tardewski. Aos poucos vamos saber que ela não falava de si nas cartas, mas "contava estranhas histórias, relatos que tinham a textura e a firmeza impessoal de uma parábola" (PIGLIA, 1987, p. 144). Parábola. Talvez seja isso o que justifica essas quatro páginas e meia que saltam à vista, que saltam ao toque, que restam como um traço incômodo que impede que o romance seja, de fato, compreendido. Porque é isto que fazem essas páginas: criam um estranhamento, são uma pedra no caminho do significado, impóem sua presença bruta e permanecem como enigma muito depois de terminado o romance.

A teoria enunciada por Sua - segundo a qual a literatura é sempre autobiográfica, "a literatura só pode ser escrita com a trama de uma vida. A gente escreve e as palavras são o nosso corpo" - e a proibição: "ao querer apagar o meu corpo no que escrevo jamais poderei escrever outra coisa que não palavras vazias, sem sangue, palavras ocas, como feitas no ar" me levaram a perguntar: quem fala pela boca de Sua? Quem diz que "a literatura não pode ter outra matéria que não a da experiência vivida” (PIGLIA, 1987, p. 149)?

Poderia responder que é o autor, Ricardo Piglia, claro, e tanto o conto $O$ fim da viagem, como os outros textos de $\mathbf{O}$ laboratório do escritor (1994) e depois, muito depois, os seus diários sáo provas irrefutáveis para essa colagem Sua/Piglia. Emílio Renzi, como alterego de Ricardo Piglia, já seria suficiente, porque aponta claramente para uma "terceirizaçáo do eu" mediante a construção de um personagem: falar de si em terceira pessoa.

${ }^{3}$ Desenvolvo essa questão no ensaio Piglia e a igreja de Arlt (MAGRI, 2020), aproveitando uma diatribe de Bolańo que acusa Piglia de ser o São Paulo de Arlt, erguendo sua igreja, dando, segundo ele, um protagonismo exagerado para um autor menor. 
Mas isso não funciona apenas para os gêneros ligados à escrita de si. Piglia diz, no epílogo de Formas breves (2004, p. 117): "A crítica é a forma moderna da autobiografia. A pessoa escreve sua vida quando crê escrever suas leituras". Pode-se dizer que essa é uma das questôes impulsionadoras de sua escrita e que, portanto, informa um modo especial de ler, aquele também defendido por Barthes (1987), no qual a escrita é o outro lado da leitura e que Piglia sintetiza, a partir de uma frase de Faulkner (1929) em O som e a fúria: "Escrevi este livro e aprendi a ler" (PIGLIA, 2004, p. 117).

Mas poderia responder também que é Arlt que fala pela voz de Sua, afinal toda a crítica construída por Piglia em torno de sua literatura é uma defesa do feio, e Nome falso (1988) constitui prova cabal para a colagem SualArlt, por Piglia. Então, caberia perguntar: por que o corpo feio é o de uma mulher? Por que é uma mulher que seduz pelo que escreve e que precisa desprezar o próprio corpo?

Essa mulher não cabe no papel de musa, constrange pela feiúra e intimida o "poeta local" ousando ser melhor escritora do que ele. Primeiro, ele precisava que ela lhe dissesse: "O senhor é o maior, o melhor, não há outro poeta como o senhor" (PIGLIA, 1987, p. 147). Mas ela era também excelente leitora e, entâo, lhe diz logo que gostava de seus sonetos "embora visse neles um excessivo desejo de impressionar através da destreza técnica" (PIGLIA, 1987, p. 148). Depois de a conhecer e ter uma ideia mais clara de seu talento, ele passa a pensar que precisaria convencê-la a deixar de escrever a qualquer custo,

porque se náo consigo convencê-la, pensava, e esta mulher, este monstro, resolve publicar qualquer coisa que escreva, quem vai ter que parar inteiramente de escrever sou eu. Se essa mulher continua escrevendo, ninguém, nos anos vindouros, ninguém jamais vai se lembrar que existira um poeta chamado Bartolomé Marconi (PIGLIA, 1987, p. 149).

O ser mulher, a assinatura Sua [musa, escrava, dona, admiradora, carrasca, mentora] é o dado mais importante. Mas não é uma mulher em seu papel comum designado pela ficção, é uma mulher monstruosa: "Era um monstro, mas tinha uma inteligência refinadíssima” (PIGLIA, 1987, p. 148). Piglia náo descreve em que consiste a feiúra de Sua, a náo ser por um detalhe: "movia-se com um requebro patético, como se atravessar o ar exigisse dela o mesmo esforço que pode exigir de qualquer um de nós caminhar pelo rio com a água pelas virilhas" (PIGLIA, 1987, p. 150). A "inteligência refinadíssima”, sim, é descrita: pela capacidade de ler e escrever 
bem, melhor do que ninguém e, neste caso, melhor do que o homem.

Quando apareceu o terceiro volume dos diários de Ricardo Piglia, $\boldsymbol{U n}$ dia en la vida (2017), o que trata dos anos 1980, encontrei uma mençáo à composição desse enigma de Respiraçáo artificial:

Viernes, 25 [janeiro de 1980]: Discusión con Iris, que leyó lo que tengo escrito en la parte central del capítulo, con la mujer que escribe bellamente pero es muy fea, como se fuera una referencia personal. Marconi sí, está lejanamente inspirado em Oswaldo Lamborguini ${ }^{4}$. (PIGLIA, 2017, p. 187)

A menção a Lamborguini não foi suficiente para mim para ligar Íris à verdadeira mulher de Piglia nos anos 80. Quem é essa mulher que se reconhece inteligente, mas que pode ser feia a ponto de tomar o enigma como uma referência pessoal?

Encontrei em O Livro de Tamar (2018), de Tamara Kamenszain, uma passagem que me ajudou a desvendar essa parte nova do enigma, a parte acrescentada pelo diário de 1980. O livro parte de um poema deixado pelo seu ex-marido [Hector Libertela], sob a porta da casa de Tamara, em 2000. Somente depois de quinze anos, mais de dez desde a morte de Hector, ela reencontra o poema no meio das coisas velhas e percebe que é possível lê-lo em chave amorosa. O livro faz catorze ensaios de interpretação para um poema de cinco versos, um título, o desenho de uma rama, uma dedicatória e uma não assinatura datada. É um livro terno, é um livro-conversa e é um livro-ensaio. É um livro-história da vida literária argentina e é um livro que convoca outros casais de escritores ligados à literatura e à crítica. E é também uma autobiografia que ensaia modos de ler (-se).

No quarto fragmento-capítulo - ou ensaio de interpretação Arma trama - Kamenszain (2018) entra um pouco na dinâmica desse casal literário e, sem aviso, passa a falar de outro casal e suas dificuldades com a crítica de um ao trabalho do outro. "Ricardo Piglia", diz ela, "en sus diários, se queja de que Josefina Ludmer, quien por entonces era su pareja, le hubiera criticado un texto depois de publicado"s. E cita: "Con Iris, antes de dormir, extraña sensación cuando ella me critica (cuando ya no hay arreglo)

\footnotetext{
4Tradução nossa: "Sexta-feira, 25 [janeiro de 1980]: Discussão com Iris, que leu o que escrevi na parte central do capítulo, com a mulher que escreve lindamente, mas é muito feia, como se fosse uma referência pessoal. Marconi, sim, é levemente inspirado em Oswaldo Lamborguini”. ${ }^{5}$ Tradução nossa: "em seus diários, se queixa de que Josefina Ludmer, quem então era sua mulher, tinha criticado um texto depois de publicado"
} 
'El fim del viaje'. Lo peor es que tiene razón, todo relato se puede mejorar..."6 (KAMENSZAIN, 2018, p. 27). Então ela explica:

Aqui, Josefina - cuyo nombre completo es Iris Josefina Ludmer — aparece como Iris. Según la situación que narre, Piglia juega con esa duplicidad aludiendo a 'Josefina L' como alguien que es parte del mundillo literario, o a 'Iris' cuando se refiere a la intimidad de la pareja' (KAMENSZAIN, 2018, p. 27-28).

Antes, nos diários dos anos 1960/70, ela aparecia como a "china Ludmer”. Então, Sua tem a ver com Ludmer? A Ludmer de Corpo de delito? Quem diz "só se pode escrever com o corpo, as palavras são o nosso corpo" (PIGLIA, 1987, p. 149) poderia ser a Josefina Ludmer? Mas ela era mesmo feia? Busco suas fotos. Bonita até na velhice. Encontro uma foto dos dois, no jornal argentino Clarín, justamente ilustrando um texto de Ana Prieto "Parejas de autores: entre la primera lectura y la critica en negativo", de 2018, mas que traz uma foto de Piglia e Ludmer nos anos $80^{8}$.

O interessante é que Piglia não nos conta de sua resposta a Iris. A frase "Marconi sim está levemente inspirado em Lamborguini", de certa forma, diz, sem dizer que não, que Sua não está inspirada em Iris. Mas é uma negação oblíqua, uma negação que encerra um segredo, não diz uma verdade.

\section{Segredo e enigma}

Ricardo Piglia faz no diário o mesmo que em sua ficção. Vai acrescentando camadas de mal-entendidos para salvaguardar aquilo que seria "a verdade" que impulsionou a escrita. Não o seu sentido último, mas o desvendamento do enigma deliberadamente plantado. Em La forma inicial. Conversaciones em Princeton, ele diz:

\footnotetext{
'Tradução nossa: "Com Iris, antes de dormir, estranha sensação quando ela critica (quando não há mais remédio) 'O fim da viagem’. O pior é que ela tem razão, todo relato pode melhorar..."

${ }^{7}$ Tradução nossa: "Aqui, Josefina - cujo nome completo é Iris Josefina Ludmer — aparece como Iris. Dependendo da situação que narra, Piglia brinca com essa duplicidade, aludindo a 'Josefina L' como alguém que faz parte do mundo literário, ou a 'Iris' quando se refere à intimidade do casal".
}

${ }^{8}$ Disponível em: https://www.clarin.com/revista-enie/literatura/primera-lectura-criticanegativo_0_By9ytIr7m.html. Acesso em: 06 fev. 2020 . 
Como manejar la información en un relato es el tema sobre el cual gira el debate de las poéticas de la narración (...) el núcleo de la información que les interesa a los personajes y al narrador no necesita ser aclarado. En ese sentido no importa la información. Y toda la cuestión del enigma y del segredo se juega ahí. Hay un elemento de información interno al relato que es necesario manejar y está el modo en que la narración cifra la información? . (PIGLIA, 2015, p. 35)

É isso que ele faz no diário. Ao manter apenas o apontamento e não o desenrolar da discussão, maneja o segredo, deixando a questão em suspenso. Se serve para pensar sua Teoria de la prosa (2019), conforme delineada em seu curso dos anos 1990 sobre Onetti, publicado em 2019 em forma de livro, e presente de maneira evidente em seus relatos e também nas Teses sobre o conto (1994), essa passagem me aproxima pouco das quase cinco páginas enigmáticas sobre Sua. A informação ocultada em Respiraçáo artificial não parece ter a ver com essas páginas, mas com o fato de Renzi esperar Marcelo Maggi durante toda essa noite enquanto Tardewski parece já saber, sem nunca dizer, que Marcelo Maggi não virá. Por que não virá? Por que foi morto? Por que está desaparecido? Por que náo quer se enfrentar com aquele passado? Isso constitui o enigma ou o segredo e nada tem a ver com a anedota — ou a parábola — de Sua, contada a Renzi por Tardewski.

Em outro texto desse mesmo livro de conversaçôes, Secreto y narración, Piglia (2015, p. 249) separa enigma e segredo:

El enigma seria, como sabemos, incluso por etimologia, dar a entender, es decir, la existência de algún elemento — puede ser un texto, una situación - que encierra un sentido que se puede decifrar. El mistério, en cambio, seria un elemento que no se comprende porque no tiene explicación, o al menos no la tiene en la lógica dentro de la cual nosotros nos manejamos (...) En cuanto el secreto, se trata también de un vacío de significación, es algo que se quiere saber y no se sabe, como el enigma y el mistério, pero en este caso es algo que alguien sabe y no dice. Es decir, el secreto es en verdad un sentido subtraído por alguien ${ }^{10}$.

\footnotetext{
9Tradução nossa: Como lidar com a informação em um relato é o tema sobre o qual gira a discussão da poética da narrativa (...) o cerne da informação que interessa aos personagens e ao narrador não precisa ser esclarecido. Nesse sentido, a informação não importa. E toda a questáo do enigma e do segredo é jogada aí. Há um elemento de informação interno ao relato que é necessário manejar e há a maneira pela qual a narração criptografa a informação.

${ }^{10}$ Tradução nossa: "O enigma seria, como sabemos, até pela etimologia, dar a entender a existência de algum elemento - pode ser um texto, uma situação - que contém um significado que pode ser decifrado. $\mathrm{O}$ mistério, por outro lado, seria um elemento que não se compreende porque não tem explicaçáo, ou pelo menos não tem na lógica dentro da qual operamos (...)
} 
Ainda poderíamos ficar em dúvida se a anedota de Sua se trata de um enigma que aponta para algo no romance, algo a ser decifrado, portanto, ou se podemos tomá-la como um segredo, neste caso, um segredo que guarda um sentido subtraído pelo autor.

Mas essa especial interpretação do segredo não cabe na definição que Piglia (2015, p. 232) daria na longa entrevista do mesmo livro Volver a empezar:

Lo que a mi me interesa del secreto es que no depende de la interpretación, no es un enigma que puede ser decifrado y por lo tanto depende de una técnica religiosa ou filológica - como quieren llamarla - que permita decifrar algo que está oculto pero que se dá a entender, en el sentido etimológico de "enigma”. El secreto es algo que está escondido. Etimologicamente también tiene que ver con un lugar donde hay algo que alguien tiene escondido y hay que entrar ahí, es una acción la que supone "descubrir" un secreto. Entonces, ahí otra vez encuentro una relación entre "sentido y lenguaje", una relación que se puede establecer alrededor de todo este juego con el que sabe algo que no quiere que los demás sepan, que, por supuesto, en el genero policial tiene un lugar importantíssimo"11.

O segredo não pede interpretação, não admite decifração. Não é da ordem das mensagens que exigem um modo especial de leitura para se abrirem a um significado oculto. É antes uma informação subtraída. Quando penso na anedota de Sua, então, ou no caso, no relato dentro de outro relato, contado, talvez, simplesmente para passar as longas horas da noite à espera de Maggi, ou para dar um pouco de contorno à figura do poeta local, quando penso, então, nesta cena, vejo que também não há nada de enigmático nela: nada que peça decifração. Tampouco há segredo. Tudo está dito: era uma vez Marconi. Ele recebeu cartas muito singulares de uma mulher que assinava Sua, antes de seu nome e sobrenome e número de

Quanto ao segredo, é também um vazio sem sentido. É algo que você quer saber e não conhece, como o enigma e o mistério, mas neste caso é algo que alguém sabe e não diz. Ou seja, o segredo é realmente um sentido subtraído por alguém”.

${ }^{11}$ Tradução nossa: "O que me interessa no segredo é que ele não depende da interpretação, não é um enigma que se decifra e, portanto, depende de uma técnica religiosa ou filológica como queiram chamar - que permita decifrar algo que está oculto mas que se dá a entender, no sentido etimológico de "enigma". O segredo é algo que está escondido. Etimologicamente também tem a ver com um lugar onde há algo que alguém escondeu e você tem que entrar lá, é uma ação que envolve "descobrir" um segredo. Entấo, aí novamente encontro uma relação entre "sentido e linguagem", uma relaçáo que pode ser estabelecida em torno de todo esse jogo com o qual ele sabe algo que não quer que outros saibam, o que, claro, no gênero policial tem um lugar muito importante". 
telefone. Cartas despidas de qualquer dado ou história pessoal, cartas que pareciam parábolas. Eram escritas em espanhol perfeito, meio quevediano, em estilo também muito singular. Marconi deseja conhecer a mulher, porque desconfia que ela é a melhor escritora que existe. Ele sente ciúmes, porque, se ela se tornar conhecida, ele será apagado da história da literatura argentina. Os dois se encontram. Resulta que a mulher é feia, "um monstro", porém muito inteligente. $\mathrm{E}$, além do mais, tem uma estranha teoria: "só se pode escrever com o corpo", "as palavras são o nosso corpo", a literatura só pode ser autobiográfica, só se pode escrever a partir da história pessoal. Ela conclui que odeia o próprio corpo, portanto, náo pode ser escritora. Marconi esconde dela que já é uma escritora, a melhor, se nega a legitimála e a despede dizendo que continue se dedicando ao que faz para ganhar a vida: a bordar panos de prato.

A interpretação é simples. Vai de um personagem a outro: a que é escritora mesmo, escritora de verdade, que alcançou uma qualidade literária invejável, não pode escrever. Acredita não poder escrever. $\mathrm{O}$ escritor legitimado se dedica a reforçar esse impedimento para manter sua posição. Estamos diante de uma clara alusão às intrigas e lutas dos escritores pela visibilidade, pela legitimação no mercado, estamos diante também da invisibilizaçáo da escrita da mulher talentosa. A questão que faz com que essa passagem pareça um enigma - pedindo decifração — é o porquê de ela estar aí onde está, aparentemente deslocada de qualquer uma das discussóes sustentadas pelos personagens na longa noite. Todos homens falando de homens. Essa aparente gratuidade faz com que adquira o status de enigma que acena para uma intençấo de autor, um desejo de insinuar algo que não está aí, que nos escapa, que não está dito e que, portanto, participa da atmosfera do segredo - um segredo alheio à trama - um segredo exterior ao texto. É esse segredo que minha leitura fareja.

O próprio Piglia me autoriza esse tipo de interesse. "Hay un sujeto que decide escribir. Entonces, no me parece que la figura de ese sujeto sea algo que deba ser excluído de la discusión de la crítica como un elemento que alteraría la verdad de la leitura" ${ }^{12 "}$ (PIGLIA, 2015, p. 221).

Há algo aí, quando Piglia faz aparecer como um fogo de artifício algo que dura menos de cinco páginas e desaparece da trama e do livro uma figura de autoria feminina de quem não se pronuncia o nome. Algo como a melhor escritora que não tem obra, porque acredita que não pode

${ }^{12}$ Tradução nossa: "Há um sujeito que decide escrever. Portanto, não me parece que a figura desse sujeito seja algo que deva ser excluído da discussão da crítica como um elemento que alteraria a verdade da leitura". 
ser escritora. Poderíamos entrar no enigma - por que essa anedota está aí? - pelo que Piglia fala sobre "o mito de escritor", na mesma entrevista Volver a empezar:

A mi me interesan mucho los mitos de escritor, me parece que junto con los textos hay un aura, ciertas imágenes que actúan, en secreto, en los resquícios, entre las palabras, como quien vislumbra un rostro cubierto con un tul (...) Hay una construcción del sujeto que es una combinación rara de palabras, acontecimientos, tragedias, datos, que habilmente quitan al sujeto de la normalidade, diría yo. El sujeto es sacado de la normalidad y ese corte está secretamente ligado a su escritura (...) Quiere decir: el mejor escritor del siglo XX, quizás, Kafka, no podia escribir. Ahí hay un mito (...) Es una relación paradójica entre el texto y el sujeto lo que funda el mito ${ }^{13}$. (PIGLIA, 2015, p. 220).

Me parece que a anedota de Sua é a ilustração dessa teoria. O grande escritor é aquele que acredita não poder escrever e esse dado exige um modo especial de ler. É aquele que crê escrever algo menor, devotado ao fracasso, à não publicação, ou à publicação depois da morte e contra sua vontade. Poderíamos, além de Kafka, pensar em outros escritores, Macedônio Fernandez, por exemplo, de quem Piglia diz ser um dos maiores escritores e só escreveu dois livros. E essa cena começa a construir a outra cena, talvez a mais importante do livro, a que fecha a noite e o relato: o encontro de Kafka com o jovem Hitler. As longas páginas sobre o hipotético encontro entre os dois em Praga sustentam também uma teoria da leitura, porque é associando as cartas e diários de um e a biografia de outro que Tardewski e mais ninguém além dele vê esse encontro. A teoria da leitura esboçada nessas páginas é esta: "Ninguém sabe ler, ninguém lê. Porque para ler, disse Tardewski, é preciso saber associar" (PIGLIA, 1987, p. 186, itálico meu). É o que vou tentar fazer aqui com Sua/Kafka.

Ao associar o início dos diários de Kafka e o que ele diz numa carta a seu amigo Rainer Jauss, Tardewski encontra a suposta prova do encontro entre Kafka e Hitler. Ele sustenta que nesse encontro Adolf, ou seja Hitler antes

\footnotetext{
${ }^{13}$ Tradução nossa: "Me interesso muito pelos mitos de escritor, me parece que junto com os textos há uma aura, certas imagens que agem, secretamente, nos resquícios, entre as palavras, como quem vislumbra um rosto coberto por um véu (...) Há uma construçâo do sujeito que é uma rara combinação de palavras, acontecimentos, tragédias, dados, que tira habilmente o sujeito da normalidade, eu diria. O sujeito é tirado da normalidade e esse corte está secretamente ligado à sua escrita (...) Quer dizer: o melhor escritor do século XX, talvez, Kafka, não podia escrever. Há um mito aí (...) É uma relação paradoxal entre o texto e o sujeito que funda o mito".
} 
de ser Hitler, teria dito a Kafka algo que o teria impressionado terrivelmente. Então ele conclui que "o gênio de Kafka foi ter compreendido que se aquelas palavras podiam ser ditas, então é porque podiam ser realizadas" (PIGLIA, 1987, p. 186). Assim, "ele é aquele que sabe ouvir" - outro modo de dizer "ler", outro modo de dizer "associar" — e "faz em sua ficção, antes de Hitler, o que Hitler lhe disse que iria fazer. Seus textos são a antecipação daquilo que via como possível nas palavras perversas daquele Adolf, palhaço, profeta que anunciava, numa espécie de sopor letárgico, um futuro de uma maldade geométrica" (PIGLIA, 1987, p. 190). Eis uma leitura por associaçáo que fornece uma chave de leitura para entender Kafka, o escritor que escrevia por parábolas, o escritor do gosto aos enigmas, o escritor impossível de decifrar. "Como era possível que ninguém tivesse entendido? Perguntara-se Tardewski. Ou será que só lemos o que já lemos diversas vezes, para procurar nas palavras o que sabemos que está nelas, sem que nenhuma surpresa possa variar seu sentido?" (PIGLIA, 1987, p. 187).

Assim como Renzi havia construído a igreja de Arlt algumas páginas antes da cena de Sua, agora Tardewski constrói a igreja de Kafka. Se Renzi construiu a igreja de Arlt contra Borges, ou pelo menos isolando Borges numa estética do século IX, ou respondendo a uma estética do século IX, enquanto Arlt fundava a modernidade argentina, agora Tardewski, algumas horas depois, dentro da mesma longa noite constrói a igreja de Kafka contra Joyce:

Joyce carrega um estandarte que diz: Sou aquele que supera todos os obstáculos, enquanto Kafka escreve num bloco e guarda num bolso da sua jaqueta abotoada esta inscrição: Sou aquele a quem todos os obstáculos superam. Kafka disse, diz Tardewski: Enfrento a impossibilidade de não escrever, a de escrever em alemão, a de escrever em outro idioma, ao que se poderia acrescentar quase uma quarta impossibilidade: a de escrever. Essa quarta impossibilidade era, para ele, a suprema tentação. Para ele que soubera dizer: qualquer coisa que eu escreva. Por exemplo a frase: Ele olhou pela janela, escrita por mim, já é perfeita. De que perfeição se tratava?, diz Tardewski. Por um lado, o ideal de Kafka quanto à perfeição formal e estilística era tão rigoroso que não tolerava transaçóes. Mas ao mesmo tempo soube melhor que ninguém que os escritores realmente grandes são aqueles que sempre enfrentam a impossibilidade quase absoluta de escrever. (PIGLIA, 1987, p. 194)

E essa contraposição entre Joyce e Kafka traz de volta a cena de Sua em que ela é, de certa forma, associada a Kafka e Marconi associado a Joyce: 
"Joyce, como dizia aquela mulher que borda toalhas referindo-se aos poemas de Marconi, é muito, como dizer-lhe?, muito laboriosamente virtuose. Um malabarista, disse. Alguém que faz jogos de palavras como outros fazem jogos de mãos" (PIGLIA, 1987, p. 193-94).

Lembro que Sua reparou em Marconi a vontade de agradar pela destreza técnica. "Kafka, em compensação, é o equilibrista que anda no ar, sem rede, e arrisca a vida tentando manter o equilíbrio, movendo um pé, depois, muito lentamente, o outro pé, sobre o arame retesado de sua linguagem." (PIGLIA, 1987, p. 194). A contraposição é elegante, mas lembra também a única possível descrição do que seria a feiúra de Sua, sua dificuldade de atravessar o ar, o simples ar, atravessando-o como os simples mortais, as pessoas normais, atravessariam um rio com a água na virilha.

Todos conhecemos as fotografias de Kafka. Ele nunca foi um escritor bonito. E seu diário está repleto de reclamaçóes contra o corpo. Uma delas: "Escrevo isso com toda certeza de desespero por meu corpo e pelo futuro com esse corpo" (KAFKA, 2018, p. 27). Sua/Kafka, parece ser o melhor gesto de aproximação pra entender um pouco essa passagem em seu teor de enigma. Mas isso nada esclarece sobre essa figuração do mito do escritor que acredita não poder escrever ser a de uma mulher. Por que o mito de escritor de Kafka aparece aqui travestido de mulher? A que modo de ler essa passagem aponta?

Poderíamos arriscar uma ideia. A de que Piglia encena uma teoria: a de que Kafka falou do século no qual os judeus sofreram o seu genocídio anunciado primeiro a ele pelo jovem Hitler. Um judeu falando da morte dos judeus de modo cifrado em sua literatura. Ao colocar em cena uma mulher que também escreve por parábolas e acredita, como Kafka, não poder escrever, Piglia estaria apontando para a existência, o surgimento, de uma mulher como a escritora de seu século. Uma mulher falando de outra coisa que não de si mesma e de seu corpo. Uma mulher falando, então, do mundo por parábolas. Uma mulher que se anuncia como a escritora mais importante do novo século mas que, se depender da legitimação masculina, vai ser sempre uma não escritora. Apenas um corpo matável? E que talvez, por isso mesmo, seria aquela capaz de ver e de escrever sobre o extermínio de mulheres que se faria visível e incômodo no final do mesmo século.

Há duas possíveis ressalvas. O mundo da literatura em Piglia, é um mundo masculino. São raríssimas as aparições de mulheres em seus livros e entrevistas. É difícil sustentar que Piglia reservaria a uma mulher o lugar de escritor do novo século. E quem escreveu de maneira mais contundente 
até agora sobre o extermínio das mulheres foi um homem: Roberto Bolaño, em seu romance 2666, póstumo, publicado em Barcelona em 2004 e no Brasil em 2010. Ele é quem mostra esse grande cemitério a céu aberto onde jazem em covas abertas, mutiladas, centenas de mulheres, cujos assassinos nunca foram punidos. E antes dele, também Sérgio Gonzáles Rodrigues, em Huesos en el deserto (2002). Embora seja justo dizer que Bolaño rende homenagem em seu livro a três mulheres importantes no trabalho de investigaçáo e de enfrentamento da sociedade mexicana e seu modo de tratar os crimes: a primeira menção é a uma "jornalista de Il manifesto" cuja matéria reverbera na Itália (BOLAÑO, 2010, p. 52); a segunda menção é a uma jornalista com nome: Guadalupe Roncal, do México, DF e atua como detetive ou "jornalista secreta" que "conhece tudo o que diz respeito aos assassinatos" (BOLAÑO, 2010, p. 290); e a terceira menção é a uma deputada, Azucena Esquivel Plata, que dá um longo depoimento ao jornalista Sérgio Gonzáles (o personagem de 2666) e entendeu que a criminalidade tem seus laços com a política.

O ensaio de Rita Laura Segato, Território, soberania e crimes de segundo estado: a escritura nos corpos das mulheres de Ciudad Juarez (2005) dá uma dimensão da complexidade que envolve a investigação desses crimes de feminicídio e, por conseguinte, faz reverberar o entrelaçamento entre verdade e ficção no livro de Bolaño (2010), não porque trate dele, mas porque mostra num ensaio a faceta perversa do enlaçamento entre o Estado, o tráfico de drogas e o mais simples preconceito contra a mulher. Sabe-se que $A$ parte dos crimes, foi a última a ser escrita por Bolaño (2010) e que ficou sem sua última revisão. Ainda assim, as duas páginas que mostram os policiais encarregados das investigaçóes tomando café da manhã e contando piadas machistas são um exemplo bruto da perversidade e do descaso com que é tratado o problema (BOLAÑO, 2010, p. 527). Recentemente, Patrícia Melo lançou Mulheres empilhadas (2019), que trata do feminicídio no Brasil, mesclando casos reais a um enredo ficcional, o que demonstra que o tema entrou para a discussão na literatura brasileira com alcance massivo, já que a autora é uma das mais lidas, dentro do gênero policial.

De todo modo, creio ser possível ler o enigma de Sua, — mesmo que à revelia de Piglia — se não como uma espécie de "profecia", então como um apontamento sobre o perigo que pode se tornar para o mundo masculino dos escritores visionários uma mulher falando do mundo e não apenas de seu corpo e de sua vida. Mas por que a mulher náo poderia falar de si? E em que medida a parábola e a escrita autobiográfica, a escrita do corpo seriam 
oponentes? A que apontaria, numa "teoria da leitura" esse embate ensaiado no "enigma de Sua"?

\section{A escrita feminina como escrita secreta}

Em $A$ citação privada, de $\mathbf{O}$ laboratório do escritor, pode haver uma pista: "Simone Weil", diz Piglia (1994, p. 63),

aponta a voz feminina como oposta à tradiçẫo escrita: o arquivo da memória se construía no corpo da mulher em oposição à escrita, ligada, desde sua origem, às técnicas do Estado, à comunicação religiosa, aos cálculos agrários. O relato feminino (Sherazade) resiste aos ditames do rei.

$\mathrm{Na}$ interdição da escrita pública, em sua clausura privada, a essa mulher - Sua, por exemplo — , resta escrever cartas, diários secretos e contar histórias. E talvez por isso se diferencia de uma escrita aderente "aos ditames do rei". Seu tema é pessoal, privado, tem a ver com a própria experiência, a vida doméstica. Piglia (1994, p. 48) pensa a escrita secreta como uma escrita feminina: "Há um assunto feminino nas escritas secretas, uma espécie de obrigaçáo de escrever às escondidas que é totalmente política”. Sua escrita secreta pessoal é o diário, que o define, desde a década de 80 , como sua obra-prima póstuma. Não necessariamente a escrita feminina é uma escrita da mulher. Uma escrita feminina é a escrita secreta, potencialmente política, desafiadora da escrita oficial.

Se nessa entrevista a citação de Simone Weil é ligada à escrita secreta e ao seu diário, curiosamente, a mesma citação aparece entre uma reflexão sobre a ligação da escrita com a divisão do trabalho, segundo Lévi-Strauss, e duas histórias sobre decifraçáo em Notas sobre literatura em um diário, de Formas breves:

A escrita está na origem da divisão do trabalho, segundo Lévi-Strauss. Não há escrita sem opressão, sem desigualdade social, não há escrita sem Estado. Mas a escrita é vista também como a origem do espírito de rebeldia: "Começou entáo a difundir-se o rancor de quem se esfalfava trabalhando para outros (escreve Li Po, cita Etiemble); tão engenhosa arte tendia diretamente a solapar as prebendas, os privilégios e o espírito dos poderosos". (PIGLIA, 2004, p. 84)

E, depois de fazer a mesma citação de Simone Weil, que nessa nova 
posição sublinha o caráter duplo da escrita, ele continua:

\begin{abstract}
A decifração das escritas secretas e das línguas perdidas como "revelação" psicótica e mística. Conta-se que, depois de trabalhar durante meses no texto escrito em sumério (que é a primeira forma de escrita conhecida), na tarde em que finalmente conseguiu ler o fragmento, George Hughtinghton, uma das glórias do departamento de arqueologia do Museu Britânico, saiu ao corredor, começou a despir-se e disse: "Após dois mil anos de silêncio, sou o primeiro a escutar essa voz". Morreu muito jovem, aos trinta e dois anos, internado numa clínica psiquiátrica nos Alpes suíços. De noite, os enfermeiros ouviam-no rir baixinho e falar com alguém numa língua exótica. (PIGLIA, 2004, p. 85)
\end{abstract}

Há aqui uma pequena história da origem da escrita que vai da opressão à artimanha e da cifra à decifraçáo como uma história reversa. Afinal, em Respiraçáo artificial é Arocena, o agente a serviço do Estado quem decifra as letras/mensagens das cartas, cujo ato de cifrar era arte para a proteção dos corpos de homens e mulheres perseguidos pelo Estado. Na história do tio Marcelo Maggi, portanto, na história familiar de Emílio Renzi, há um segredo ligado a uma mulher entrelaçado a outro segredo, de Estado. E é nessa tensão que o livro se sustenta. Numa tensão de decifração. Entre a história familiar e a história política nacional. Mas também entre a escrita como carta condenatória e a escrita como libertadora, repositório de uma verdade. Entre duas espécies de segredo que definem a vida de Marcelo Maggi. São esses dois segredos, o público e o privado, que traçam o enredo. "Dá uma história?" A pergunta que abre o livro tem a ver com uma primeira carta do tio e uma foto "eu no colo dele". Eu, o autobiográfico, e ele, a biografia, o tio desaparecido e que só se deixa ver por cartas. Mas tem a ver também com o arquivo de Henrique Ossório.

Um primeiro desaparecimento tem a ver com uma mulher: é o que se deixa ver primeiro. Mas logo entendemos, cifrada na relação entre Maggi e o Senador, a segunda história, a história secreta, aquela que ultrapassa o círculo familiar e vai para o foro público. Esperancita é a mulher fatal, pertencente à casa, alheia à vida pública do pai e do marido. A mulher oficial que é abandonada depois de seis meses de casamento. Coca, a outra, é a mulher da vida - bailarina de cabaré - e da vida pública. É ela que devolve o dinheiro de Esperancita enquanto Marcelo Maggi está na cadeia. E é somente muito depois que se fica sabendo, por uma carta deixada por Esperancita pouco antes de morrer, que Marcelo não tinha fugido com seu dinheiro depois de seis meses de casamento. Mas Marcelo é categórico: "não se deve permitir 
que alterem nosso passado" (PIGLIA, 1987, p. 15). E assim ficamos sem saber qual das duas histórias de Esperancita é a verdadeira. Assim como não sabemos qual é a verdade sobre Enrique Ossório, em cuja biografia trabalha Maggi e depois Renzi, se foi um espião a serviço de ou contra Rosas. Só "dá uma história” porque há muitos mal-entendidos a serem contados e porque se pode cifrar a história Argentina na história pessoal e vice-versa. Aqui, a escrita secreta, a escrita feminina, a carta esclarecedora que se guarda como um segredo de túmulo se entrelaça com a história masculina, de segredos de Estado, mas sem que nunca mudem de polos. Os segredos femininos permanecem os "assuntos femininos". E só dá uma história por causa da reversibilidade ler/escrever. Piglia escreve a leitura de Renzi das pistas deixadas pelo tio desaparecido. Apenas pistas que pedem para ser associadas mas que não revelam nenhuma verdade.

Pelo diário de Piglia, sabemos que era sua intençáo terminar o relato com "o monólogo de Coca", que não aparece na versão final do romance e que entrelaçaria os assuntos femininos e os assuntos de Estado. Ao que tudo indica, Piglia descobriu durante a escrita que seria melhor não revelar o segredo, náo permitir que Coca revelasse o segredo de Maggi. O segredo de sua dupla desaparição.

Lunes, 5 [março, 1979]

Novela. 1. El tío Maggi. 2. Arocena. 3. Viaje del narrador a Concordia. Maggi está desaparecido. Conversa con Tardewski y va a ver a Coca. 4. Monólogo de la Coca. 5. El archivo. (PIGLIA, 2017, p. 158)

Martes 12 [junho, 1979]

No avanzo en el monólogo de Coca, la ex mujer de Marcelo Maggi que vive del otro lado del río, en Uruguay. Descarto, sin estar muy seguro, la posibilidad de que todo esté contado por el narrador. Tal vez, entonces, un delirio de Coca, que habla sola. (PIGLIA, 2017, p. 178)

\section{Miércoles 13}

No sé qué historia debo contar y tampoco encuentro el tono. Monólogo de la Coca "hablado", ¿̨un registro de la voz? El narrador está con un grabador. ¿Se podrá escribir de otro modo? No encuentro el camino, no hay anécdota. Después de varias horas de trabajo escribo un borrador de un monólogo de la Coca, seis páginas que he vuelto a leer recién. No parece estar nada mal, quizá ella es la única que cuenta la historia del secuestro de Marcelo (PIGLIA, 2017, p. 178, grifo meu). 


\begin{abstract}
Sábado 16
¿El monólogo de la Coca podrá ser el capítulo II de la novela? En ese caso, el viaje del narrador a verla se habrá anticipado y podría cerrarse ahí la primera parte, antes de entrar en el archivo. Entonces podría ser algo así pero todavía no sé cuál es. Quizá un resumen final del narrador que ya ha leído el archivo y conversa de todo eso con Coca. ¿Pero no es reiterar la conversación de Tardewski? (PIGLIA, 2017, p. 179) ${ }^{14}$
\end{abstract}

E então já em janeiro de 1980:

Martes 8

Plan de trabajo. 1. El Senador. 2. Censor. 3. Tardewski. 4. Maggi-Renzi. 5. Pasar todo en limpio. (PIGLIA, 2017, p. 186-87) ${ }^{15}$

O monólogo de Coca desaparece da versão final, mas ela é a guardiã do segredo ou da "verdade da história de Marcelo Maggi" e que nunca é contado, permanecendo como a história cifrada, modelo descrito nas teses sobre o conto. O leitor é levado a sentir o náo dito que entrelaça as duas histórias, a pessoal, familiar e a política, nacional.

Em que medida o enigma de Sua aponta para o monólogo de Coca? O monólogo de Coca foi cifrado na estranha conversa sobre o relato autobiográfico de Sua? O nome elidido da remetente das estranhas cartas

${ }^{14}$ Tradução nossa: "Segunda-feira, 5 [março de 1979]: Novela. 1. Tio Maggi. 2. Arocena. 3. Viagem do narrador a Concordia. Maggi está desaparecido. Ele conversa com Tardewski e vai ver Coca. 4. Monólogo da Coca. 5. O arquivo.

Terça-feira, 12 [junho de 1979]:Não avanço no monólogo de Coca, a ex-mulher de Marcelo Maggi que mora na outra margem do rio, no Uruguai. Excluo, sem ter muita certeza, a possibilidade de que tudo seja contado pelo narrador. Talvez, entâo, um delírio de Coca, que fala sozinha.

Quarta-feira, 13: Não sei que história contar e também não consigo encontrar o tom. Monólogo de Coca "falado", um registro da voz? O narrador está com um gravador. Pode ser escrito de outra maneira? Não consigo encontrar o caminho, não há argumento. Depois de várias horas de trabalho, escrevo um rascunho de um monólogo da Coca, seis páginas que acabo de reler. Não parece nada mal, talvez ela seja a única a contar a história do sequestro de Marcelo.

Sábado,16: O monólogo da Coca poderia ser o capítulo II do romance? Nesse caso, a viagem do narrador para vê-la terá sido antecipada e a primeira parte poderá ser encerrada aí, antes de entrar no arquivo. Entáo pode ser algo assim, mas ainda náo sei o que é. Talvez um resumo final do narrador que já leu o arquivo e fala sobre tudo isso com a Coca. Mas não é repetir a conversa de Tardewski?"

${ }^{15}$ Tradução nossa: "Terça, 8: Plano de trabalho. 1. O senador. 2. Censor. 3. Tardewski. 4. Maggi-Renzi. 5. Passar tudo a limpo”. 
seria "tia Coca”? Não há como responder a essas perguntas, mas talvez, a partir dessa vinculação, seja possível ler de outro modo o autobiográfico de que fala Sua: um falar de si que traz o perigo da tortura e do desaparecimento pelas forças do Estado. "Nós falamos e nossas palavras são o nosso corpo". O corpo passível de todos os tormentos. O corpo que sofre a violência do Estado. Por que o "sequestro" de Marcelo Maggi, sobre o qual não se fala, náo está ligado ao casamento com Esperancita que náo deu certo, mas ao casamento com o arquivo, que permanece para sempre censurado. Ao levantar a história de Enrique Ossório, tanto no passado como no presente da narrativa, Marcelo Maggi encontra a força do Estado que censura e faz desaparecer o corpo que fala/escreve.

O corpo de Sua, o desespero de Kafka diante do próprio corpo, como um índice da fragilidade da vida diante da desmesurada força do Outro oficial. "O discurso da ação é falado com o corpo. 'O discurso da ação', disse o senador, 'é falado com o corpo'. Como o senhor vê, sou um paralítico" (PIGLIA, 1987, p. 40). Além da ênfase dada na repetição, podemos ler no mesmo parágrafo:

'As palavras são a única coisa que possuo. E direi mais', disse o senador, 'as palavras são minha única atividade. Portanto, em resumo, não devo ser considerado representativo, visto que as outras funçóes que poderiam ajudar-me a apoiar minhas palavras com o corpo estáo atrofiadas. (PIGLIA, 1987 , p. 40).

Qualquer semelhança é mera coincidência? Um homem público que se tornou paralítico não pode ser considerado representativo. Uma mulher escritora, cujo corpo não é o representativo da mulher na sociedade, não pode ser escritora. Uma mulher feia é igual a um homem paralítico? É preciso lembrar que aos dois é reservado apenas o direito de escrever cartas. $\mathrm{Ou}$ seja, suas ideias ficam restritas ao círculo íntimo. Ambas personagens falam apenas uma vez, cada um uma única cena, cada um testemunhando a presença corporal elidida das cartas.

\section{"Tudo o que vivemos se apaga"}

No enigma de Sua estão duas coisas mais: a frase final das Investigaçôes filosóficas, de Wittgenstein, que abre a segunda parte de Respiração artificial e que é citada por Tardewski ao falar de sua experiência sob influência de 
seu mestre "Sobre aquilo de que não se pode falar, é preciso calar" (PIGLIA, 1987, p. 152), e toda uma história sobre sua admiração sobre o fracasso ou sobre os tipos fracassados, longa cadeia que inclui, claro, Kafka, Wittgenstein e o próprio Tardewski. A outra coisa é uma espécie de "moral da história" de Sua: "Porque outra das virtudes do fracasso, disse, é que nos ensina que nada jamais deixa sua marca no mundo. Tudo o que vivemos se apaga e isso talvez, disse, é o que aquela mulher da história de Marconi compreendera" (PIGLIA, 1987, p. 150). As palavras vão embora com o nosso corpo.

Não esqueçamos que a epígrafe do livro Respiraçáo artificial é de T. S. Eliot: "We had the experience but missed the meaning, and approach to the meaning restores the experience" 16 . Todas as vozes que aparecem no romance reverberam essa epígrafe. Todos tratam de dar algum sentido a suas experiências ainda que só se deparem com equívocos. E é com esses equívocos que, talvez, se possa decifrar de novo a vida vivida. É isso que Piglia defende no belo texto de $\mathbf{O}$ último leitor (2006): "Uma narrativa sobre Kafka" e que eu, outra vez, associo com Sua.

Trata-se de dar contorno à figura da leitora ideal tal qual Felice aparece para Kafka na noite em que a conhece. Piglia narra, associando (com o mesmo procedimento de Tardewski em Respiraçáo artificial) suas cartas a Felice e o conto $O$ veredito. Nessa narrativa, sustenta que Kafka "descobre uma nova maneira de ler: a literatura dá forma à experiência vivida, constrói-a como tal e a antecipa" (PIGLIA, 2006, p. 50) e que "a escrita é um resumo da vida, condensa a experiência e a torna possível" (PIGLIA, 2006, p. 51).

E como Piglia descobre que Kafka faz isso? Reconstruindo o encontro Kafka-Felice pela chave escritor-leitora ideal. Seguindo as pegadas das cartas e do conto para reconstruir por "caminhos tortuosos" os acontecimentos da vida que se transformam em acontecimentos de escrita e que, por sua vez, voltam a constituir os acontecimentos da vida. Mas tudo isso, sem que o escritor, Kafka, se dê conta deles antes de tê-los escrito. Ao reler as cartas, bem como as biografias, o diário e a ficção de Kafka, Piglia sublinha as passagens que vão delineando nele o desejo e a sedução da leitora que, nunca, no entanto, poderá se tornar sua mulher, fora de seu papel de empregada disposta a ler e copiar o que ele escreve. Nesse sentido, poderíamos pensar em Sua como a leitora-copista-empregada ideal para Kafka: aquela que não poderia seduzi-lo, aquela que sabe que não pode seduzir e que permanece

${ }^{16}$ Tradução de Ivan Junqueira (ELIOT, 1981, p. 215): "Vivemos a experiência mas perdemos o significado, e a proximidade do significado restaura a experiência". 
disponível, à distância, como inspiradora, comentadora, musa, escrava, etc. Mas essa mulher não quer ser a copista ou leitora ideal. Quer ser Kafka.

Piglia começa por um poema chinês que Kafka manda a Felice "Na noite profunda" no qual uma mulher toma de um homem uma lamparina e pergunta: "sabe que horas são?". Uma mulher que, para Kafka, encarna seu maior temor: a mulher que produz a interrupção da escrita. A mulher que impede a escrita, o isolamento e o silêncio. Ele manda essa carta com o poema a Felice no dia 24 de novembro de 1912. No dia 23 de setembro, dois meses antes, havia escrito "O veredito" numa noite, sem interrupção. Ele escreve em seu diário todas as sensaçóes de esgotamento mas também de maravilhamento pelo feito. A cena ideal de escrita acaba assim: "Antes, espreguiçar-me diante da empregada e dizer: 'Fiquei até agora escrevendo'. $\mathrm{O}$ aspecto de minha cama, intacta, como se a tivessem trazido naquele instante mesmo" (KAFKA in PIGLIA, 2006, p. 47). Piglia lê esse relato da noite da escrita como a inversão perfeita da noite do poema chinês.

Em outra anotaçáo do diário, Kafka escreve que deve a história a Felice, "por caminhos tortuosos". Passa a escrever a ela, porque quer entender a razão disso. "Dessa forma se define um nexo entre a escrita e a vida que não pertence à categoria do autobiográfico" (PIGLIA, 2006, p. 49). Me parece que este é o modelo que Piglia busca e que faz Sua defender. Uma relação entre escrita/leitura e vida que está impregnada da experiência, mas que as relaçôes entre uma e outra sejam cifradas a tal ponto que o autobiográfico se transforma em outra coisa. Em enigma. Pela parábola. Uma escrita/leitura que permite explicar, ou pelo menos, fazer ver o vivido. A exata proposição da citação de T. S. Eliot.

\section{Referências}

BARTHES, R. O prazer do texto. São Paulo: Perspectiva, 1987.

BOLAÑO, Roberto. 2666. Trad. Eduardo Brandão. São Paulo: Companhia das Letras, 2010.

ELIOT. T. S. Poesia. Trad. Ivan Junqueira. Rio de Janeiro: Nova Fronteira, 1981.

KAFKA, F. Diários 1909-1912. Trad. Renato Zwick. Porto Alegre: LP\&M, 2018.

KAMENSZAIN, T. El libro de Tamar. Buenos Aires: Eterna Cadência, 2018. 
LUDMER, Josefina. O corpo do delito. Belo Horizonte: UFMG, 2002. MAGRI, Ieda. Piglia e a igreja de Arlt. ALEA. Revista de estudos Neolatinos. Rio de Janeiro, vol. 22/2, p. 119-136, mai-ago. 2020. Disponível em: https://revistas.ufrj.br/index.php/alea/article/view/40450.

MELO, Patrícia. Mulheres empilhadas. São Paulo: Leya, 2019.

PIGLIA, Ricardo. Formas breves. Trad. José Marcos Mariani de Macedo. São Paulo: Cia. das Letras, 2004.

Respiraçáo artificial. Trad. Heloisa Jahn. São Paulo: Iluminuras, 1987.

Nome falso. Trad. Heloisa Jahn. São Paulo: Iluminuras, 1988.

2006.

. O último leitor. Trad. Heloisa Jahn. São Paulo: Cia das Letras,

. La forma inicial. Conversaciones en Princeton. Buenos Aires: Eterna Cadência, 2015.

. Teoria de la prosa. Buenos Aires: Eterna Cadência, 2019.

. O laboratório do escritor. Trad. Josely Vianna Baptista. São Paulo: Iluminuras, 1994.

. Los diarios de Emilio Renzi. Un día en la vida. Volume 3. Apple Books, 2017.

PRIETO, Ana. "Parejas de autores: entre la primera lectura y la critica en negativo". Clarín, Revista Ñ, 12/07/2018. Disponível em: https:/www. clarin.com/revista-enie/literatura/primera-lectura-critica-negativo 0 By9ytIr7m.html. Acesso em: 26 fev. 2020

RODRIGUES, Sérgio Gonzáles. Huesos en el deserto. Barcelona: Anagrama, 2002.

SEGATO, Rita Laura. Território, soberania e crimes de segundo Estado: a escritura nos corpos das mulheres de Ciudad Juarez. Rev. Estud. Fem., Florianópolis, v. 13, n. 2, p. 265-285, agosto de 2005. Disponível em: <http://www.scielo.br/scielo.php?script=sci_arttext\&pid=S0104-026X2005000200003\&lng=en\&nrm=iso $>$. Acesso em: 26 fev. 2020. https://doi.org/10.1590/S0104-026X2005000200003. 